\title{
UJI DAYA HAMBAT EKSTRAK ETIL ASETAT DAUN BINAHONG (Anredera coliforlia (Ten.) Steenis) TERHADAP PERTUMBUHAN BAKTERI Staphylococcus aureus DAN Escherichia coli.
}

\author{
Wahyuddin Jumardin, Masnawati \\ Sekolah Tinggi Ilmu Kesehatan Mega Rezky Makassar \\ Email : wandy271185@gmail.com
}

\begin{abstract}
Binahong (Anredera coliforlia (Ten.) Steenis) is a potential medicinal plants that can superintend with different kinds of diseases. Research on antibacterial activity of binahong leaves and the secondary metabolites content ever done that in binahong leaves contained alkaloids, saponins, polyphenols. This research is a laboratory experiments that aim to find out the inhibition of leaves binahong ethyl acetate extract (Anredera coliforlia (Ten.) Steenis) against bacteria test. Binahong leaf extract work done by maceration method. Bacteria test i.e. Staphylococcus aureus and Escherichia coli. The zone of inhibition are determined for concentration ranging between $5 \%, 10 \%, 15 \%$, and $20 \%$. Test of antibacterial activity is done using paper discs and disc diffusion method. The results of research can be drawn the conclusion that the ethyl acetate extract, binahong leaves at concentrations of $5 \%$ inhibition zone not seen against the bacteria Staphylococcus aureus, Escherchia coli and bacteria while at concentrations of $10 \%, 15 \%$ and $20 \%$ visible inhibition zone against both the bacteria i.e. $1.7 \mathrm{~mm}, 2.0 \mathrm{~mm}$ and $2.6 \mathrm{~mm}$ for the bacteria Staphylococcus aureus and $1.8 \mathrm{~mm}$ and $2.3 \mathrm{~mm} 2.8 \mathrm{~mm}$ for the bacterium Escherichia coli. It can be said that the extract of binahong leaves influential ethyl acetate can potentially inhibit the growth of Staphylococcus aureus and Escherichia coli, and based on the diameter of the inhibition zone caused by any concentration of the extract can also be inferred that the higher the concentration of a sample is then the higher the diameter of the inhibition zone is generated.
\end{abstract}

Key words : Antibacterial, binahong leaf extract, inhibition zone, Staphylococcus aureus, Eschericia coli, diffusion disk.

\section{PENDAHULUAN}

Sejak zaman dahulu masyarakat Indonesia telah mengenal dan menggunakan tanaman sebagai obat. Kemampuan meracik tumbuhan berkhasiat obat biasanya didapat berdasarkan pengalaman yang diwariskan secara turun-temurun.
Umumnya obat tradisional digunakan dengan cara direbus, dimakan langsung, ataupun diperas untuk diambil sarinya.

Pemanfaatan bahan alami sebagai obat cenderung mengalami peningkatan dengan adanya kesadaran untuk kembali ke alam 
Uji daya hambat ekstrak etil asetat daun binahong (Anredera coliforlia (Ten.) Steenis) terhadap pertumbuhan bakteri Staphylococcus aureus dan Escherichia coli.

(back to nature) untuk mencapai kesehatan yang optimal. Keuntungan menggunakan tanaman sebagai obat tradisional antara lain relatif lebih aman, mudah diperoleh, tidak menimbulkan resistensi, dan relatif tidak berbahaya terhadap lingkungan sekitarnya. Obat tradisional memiliki efek samping yang jauh lebih rendah tingkat bahayanya dibandingkan obatobatan modern, sehingga tubuh manusia relatif lebih mudah menerimanya.

Penyakit infeksi merupakan salah satu masalah kesehatan global baik di negara maju dan terlebih di negara berkembang seperti Indonesia. Data statistik menunjukkan bahwa penyakit infeksi sebagai penyebab kematian kedua dinegara berkembang setelah penyakit jantung. Salah satu penyakit infeksi yang masih sering menimbulkan kejadian luar biasa dengan penderita yang banyak dalam waktu yang singkat adalah diare yang disebabkan oleh Echerichia coli. Jumlah kasus diare pada tahun 2010 sebanyak 2.580 dengan kematian sebesar 77 kasus. Selain itu Staphylococcus aureus yang dapat menyebabkan penyakit pneumonia, meningitis, endokarditis, dan infeksi kulit (Setiaji, 2009). Tanaman yang digunakan sebagai obat tradisional biasa berupa buah, sayur mayur, bumbu dapur, tanaman hias dan bahkan tanaman liar yang tumbuh disembarang tempat. Salah satu tanaman yang dapat dipakai sebagai obat tradisional adalah binahong (Anredera coliforlia (Ten.) Steenis). Tanaman binahong (Anredera coliforlia (Ten.) Steenis) adalah tanaman obat potensial yang dapat mengatasi berbagai jenis penyakit. Tanaman ini berasal dari dataran Cina dengan nama asalnya adalah dheng shan chi, dikenal dengan sebutan Madeira vine (Manoi, 2009).

Bagian tanaman binahong yang bermanfaat sebagai obat pada umumnya adalah rhizome, akar dan daun (Susetya, 2010). Sehubungan dengan adanya indikasi bahwa daun binahong mempunyai daya antibakteri serta belum diketahui lebih lanjut mengenai efek antibakteri ekstrak daun binahong, maka perlu dilakukan penelitian tentang daya antibakteri ekstrak daun binahong. Pada penelitian ini akan dilakukan pengujian daya antibakteri terhadap Staphylococcus aureus dan Echerichia coli.

Khunaifi, mufid (2010) telah melakukan penelitian tentang uji antibakteri ekstrak etil asetat daun binahong dengan konsentrasi $25 \%$, 
Uji daya hambat ekstrak etil asetat daun binahong (Anredera coliforlia (Ten.) Steenis) terhadap pertumbuhan bakteri Staphylococcus aureus dan Escherichia coli.

$30 \%$, 35\%, 40\%, $45 \%$ dan $50 \%$.

Penelitian ini menunjukkan pada konsentrasi $25 \%$ telah dapat menghambat pertumbuhan bakteri gram-positif (Staphylococcus aureus) dan bakteri gram-negatif (Pseudomonas aeruginosa).

\section{METODE PENELITIAN}

\section{Alat dan bahan yang digunakan}

Alat yang digunakan dalam penelitian ini yaitu timbangan analitik, toples, cawan petri, tabung reaksi, labu erlenmeyer, pinset, batang pengaduk, lampu spiritus, oven, inkubator, kertas cakram, rak tabung, sendok tanduk, blender, jangka sorong, kain saring, pipet tetes, pipet volum, penangas, gelas ukur, jarum ose, kaca arloji, mikroskop, kertas label, kapas dan aluminium foil.

Bahan-bahan yang digunakan dalam penelitian ini adalah daun binahong (Anredera coliforlia (Ten.) Steenis), biakan murni bakteri Staphylococcus aureus dan Escherichia coli, medium Nutrient Agar (NA), tetrasiklin, $\mathrm{NaCl}$, aquadest, etil asetat, dan alkohol.

\section{Prosedur kerja}

\section{Persiapan sampel}

Daun binahong sebanyak $1 / 2 \mathrm{~kg}$ di cuci bersih dan ditiriskan, kemudian dikeringkan dengan cara dianginanginkan dan tidak terkena sinar matahari langsung. Kemudian dihaluskan menggunakan blender sampai berbentuk serbuk. Serbuk daun binahong ini disebut sebagai sampel.

\section{Ekstrak daun binahong dengan metode maserasi}

Serbuk daun binahong yang telah dihaluskan dimasukkan kedalam toples dan ditambahkan pelarut etil asetat, kemudian digojok hingga mencapai kondisi homogen. Selanjutnya larutan dimaserasi selama 24 jam pada suhu kamar. Setelah 24 jam, larutan difiltrasi atau dipisahkan dengan menggunakan kain saring. Kemudian residu penyaringan dianginanginkan dan dilakukan remaserasi ulang selama 24 jam, maserasi diulang sebanyak 2 kali. Hasil saringan 1 dan 2 dicampur lalu dipekatkan dengan menggunakan kipas angin sampai didapatkan ekstrak pekat. Ekstrak pekat yang diperoleh digunakan untuk uji antibakteri.

\section{Sterilisasi alat dan bahan}

Seluruh alat-alat dicuci bersih dan dikering anginkan. Kemudian alatalat seperti labu erlenmeyer, gelas kimia, cawan petri, gelas ukur, pipet tetes, pipet volum dan tabung reaksi dibungkus kertas serta diikat tali. Dan bersama bahan-bahan seperti aquadest, kertas cakram dan media 
Uji daya hambat ekstrak etil asetat daun binahong (Anredera coliforlia (Ten.) Steenis) terhadap pertumbuhan bakteri Staphylococcus aureus dan Escherichia coli.

yang akan digunakan disterilkan dengan menggunakan oven pada suhu $170^{\circ} \mathrm{C}$ selama 1 jam.

\section{Pembuatan larutan kontrol positif}

Dibuat larutan tetrasiklin dengan cara ditimbang sebanyak 1 gram kemudian dilarutkan dalam 100 $\mathrm{ml}$ aquadest lalu didihkan pada penangas air hinggah berubah menjadi bening.

\section{Pembuatan larutan uji}

Dibuat larutan uji 5\%, 10\%, $15 \%$ dan $20 \% \mathrm{v} / \mathrm{v}$ dengan cara ditimbang $5 \mathrm{ml}, 10 \mathrm{ml}, 15 \mathrm{ml}$ dan $20 \mathrm{ml}$ ekstrak daun binahong kemudian masing-masing dicampur aquadest sebanyak $100 \mathrm{ml}$.

\section{Pembuatan medium}

Medium agar miring (Safitri et al., 2010)

Pembuatan medium dilakukan dengan cara ditimbang Nutrien Agar (NA) sebanyak 0,6 gram kemudian dimasukkan kedalam erlenmeyer dan ditambahkan aquadest sebanyak 20 $\mathrm{ml}$ untuk melarutkan, lalu dihomogenkan diatas penangas air mendidih. Sebanyak $5 \mathrm{ml}$ dituang pada dua tabung reaksi steril dan ditutup dengan aluminium foil. Proses ini dilakukan secara aseptik, kemudian disterilkan di dalam autoklaf pada suhu $121^{\circ} \mathrm{C}$ selama 15 menit. Setelah itu dibiarkan pada suhu ruangan \pm 30 menit sampai medium memadat pada kemiringan $30^{\circ} \mathrm{C}$

Medium dasar dan medum
pembenihan

Medium dasar dibuat dengan cara ditimbang Nutrien Agar (NA) sebanyak 2,3 gram lalu dilarutka dengan $100 \quad \mathrm{ml}$ aquadest menggunakan Erlenmeyer. Lalu didihkan pada penangas air hingga berubah menjadi bening. Sebanyak 10 $\mathrm{ml}$ dituang kedalam cawan petri steril lalu dibiarkan hingga memadat. Proses ini dilakukan secara aseptik.

\section{Pembuatan suspensi bakteri}

Diambil $1 \mathrm{ml}$ dari hasil peremajaan biakan murni bakteri Staphylococcus aureus dan Escherchia coli dimasukkan ke dalam tabung reaksi yang berisi $5 \mathrm{ml} \mathrm{NaCl}$ fisiologis $\quad 0,9 \% \quad$ kemudian dihomogenkan.

\section{Uji aktifitas antibakteri ekstrak daun binahong}

Uji aktifitas antibakteri ekstrak daun binahong dilakukan dengan menggunakan metode difusi yaitu disiapkan medium Nutrien Agar (NA) steril dengan suhu $45^{\circ} \mathrm{C}-47^{\circ} \mathrm{C}$ lalu dituang secara aseptik kedalam 2 cawan petri steril yang telah disiapkan masing-masing sebanyak $10 \mathrm{ml}$ dan dibiarkan hingga memadat, ini merupakan lapisan dasar (Base 
Uji daya hambat ekstrak etil asetat daun binahong (Anredera coliforlia (Ten.) Steenis) terhadap pertumbuhan bakteri Staphylococcus aureus dan Escherichia coli.

Layar). Setelah itu dicampur $10 \mathrm{ml}$ medium Nutrien Agar dan 0,2 suspensi bakteri uji dalam tabung reaksi steril lalu dituang diatas permukaan medium Nutrien Agar yang telah memadat tadi, kemudian digoyang-goyangkan secara teratur sehingga membentuk lapisan yang homogen dan dibiarkan setengah memadat (Seed Layer). Direndam 4 kertas cakram dalam ekstrak sampel dan 1 kertas cakram dalam kontrol kemudian ditempatkan kertas cakram tersebut secara aseptik dalam masingmasing cawan petri yang berisi bakteri Staphylococcus aureus dan Escherichia coli secara diagonal \pm 2 menit dan selanjutnya diinkubasi pada suhu $37^{\circ} \mathrm{C}$ selama $1 \times 24$ jam.

\section{Pengamatan dan pengukuran}

Setelah 24 jam, cawan petri yang berisi perlakuan dikeluarkan dari inkubator, kemudian dilakukan pengukuran zona hambat terhadap pertumbuhan bakteri disekitar kertas cakram dengan menggunakan jangka sorong. Pengukuran dilakukan dengan terlebih dahulu membalikkan cawan petri sehinggah terlihat daerah hambatan yang transparan disekitar kertas cakram, kemudian jangka sorong diletakkan pada permukaan tutup cawan petri, tepat di atas zona hambatan yang akan diukur. Posisi paruh jangka sorong (rahang tetap dan rahang sorong) terletak selurus dengan zona hambatan yang akan diukur. Kemudian geser rahang sorong sesuai dengan besarnya diameter zona hambatan yang terlihat. Selanjutnya pembacaan dilakukan pada skala utama dan skala nonius pada jangka sorong untuk menentukan besarnya diameter zona hambatan dalam satuan millimeter $(\mathrm{mm})$.

Pembacaan hasil negatif jika disekitar kertas cakram tidak terdapat zona jernih, berarti ekstrak daun binahong (Anredera coliforlia (Ten.) Steenis) yang diuji tidak mempunyai daya antibakteri. Pembacaan hasil positif jika disekitar kertas cakram terdapat zona jernih, yaitu zona yang tidak ditumbuhi bakteri, berarti ekstrak daun binahong mempunyai daya antibakteri. Pengukuran diameter zona hambat dilakukan secara vertikal ( misal a mm), horizontal (misal b $\mathrm{mm}$ ) dan miring (misal c mm). Kemudian ketiganya dijumlah dan dibagi 3 (misal n). 
Uji daya hambat ekstrak etil asetat daun binahong (Anredera coliforlia (Ten.) Steenis) terhadap pertumbuhan bakteri Staphylococcus aureus dan Escherichia coli.

\section{HASIL PENELITIAN}

Tabel 1. Hasil pengukuran diameter zona hambat $(\mathrm{mm})$ eksrak etil asetat daun binahong (Anredera coliforlia (Ten.) Steenis) terhadap pertumbuhan bakteri Staphylococcus aureus.

\begin{tabular}{|c|c|c|}
\hline \multicolumn{3}{|c|}{ Bakteri uji Staphylococcus aureus } \\
\hline $\begin{array}{l}\text { Konsentrasi ekstrak etil } \\
\text { asetat daun binahong (\%) }\end{array}$ & $\begin{array}{l}\text { Hasil pengukuran zona hambat } \\
\text { (vertikal, horizontal, miring) }\end{array}$ & $\begin{array}{c}\text { Rata-rata diameter zona } \\
\text { hambat }(\mathrm{mm})\end{array}$ \\
\hline $5 \%$ & $\begin{array}{l}0 \mathrm{~mm} \\
0 \mathrm{~mm} \\
0 \mathrm{~mm}\end{array}$ & $0 \mathrm{~mm}$ \\
\hline $10 \%$ & $\begin{array}{l}1,9 \mathrm{~mm} \\
1,7 \mathrm{~mm} \\
1,6 \mathrm{~mm}\end{array}$ & $1,7 \mathrm{~mm}$ \\
\hline $15 \%$ & $\begin{array}{l}2,1 \mathrm{~mm} \\
2,0 \mathrm{~mm} \\
1,9 \mathrm{~mm}\end{array}$ & $2,0 \mathrm{~mm}$ \\
\hline $20 \%$ & $\begin{array}{l}2,6 \mathrm{~mm} \\
2,5 \mathrm{~mm} \\
2,6 \mathrm{~mm}\end{array}$ & $2,6 \mathrm{~mm}$ \\
\hline
\end{tabular}

Tabel 2. Hasil pengukuran diameter zona hambat $(\mathrm{mm})$ eksrak etil asetat daun binahong (Anredera coliforlia (Ten.) Steenis) terhadap pertumbuhan bakteri Escherichia coli.

\begin{tabular}{|c|c|c|}
\hline \multicolumn{3}{|c|}{ Bakteri uji Escherichia coli } \\
\hline $\begin{array}{l}\text { Konsentrasi ekstrak etil } \\
\text { asetat daun binahong (\%) }\end{array}$ & $\begin{array}{l}\text { Hasil pengukuran zona hambat } \\
\text { (vertikal, horizontal, miring) }\end{array}$ & $\begin{array}{c}\text { Rata-rata diameter zona } \\
\text { hambat }(\mathrm{mm})\end{array}$ \\
\hline (1) & $\begin{array}{l}0 \mathrm{~mm} \\
0 \mathrm{~mm} \\
0 \mathrm{~mm}\end{array}$ & $0 \mathrm{~mm}$ \\
\hline $10 \%$ & $\begin{array}{l}1,9 \mathrm{~mm} \\
1,7 \mathrm{~mm} \\
1,7 \mathrm{~mm}\end{array}$ & $1,8 \mathrm{~mm}$ \\
\hline $15 \%$ & $\begin{array}{l}2,8 \mathrm{~mm} \\
2,1 \mathrm{~mm} \\
1,9 \mathrm{~mm}\end{array}$ & $2,5 \mathrm{~mm}$ \\
\hline $20 \%$ & $\begin{array}{l}3,0 \mathrm{~mm} \\
2,6 \mathrm{~mm} \\
2,8 \mathrm{~mm}\end{array}$ & $2,8 \mathrm{~mm}$ \\
\hline
\end{tabular}

Tabel 3. Hasil pengukuran daya hambat larutan kontrol positif (+) terhadap Staphylococcus aureus.

\begin{tabular}{ccc}
\hline & Bakteri uji Staphylococcus aureus & \\
\hline $\begin{array}{c}\text { Larutan kontrol positif } \\
(+)\end{array}$ & $\begin{array}{c}\text { Hasil pengukuran zona hambat } \\
\text { (vertikal, horizontal dan miring) }\end{array}$ & $\begin{array}{c}\text { Rata-rata diameter zona } \\
\text { hambat }(\mathbf{m m})\end{array}$ \\
\hline \multirow{2}{*}{ Tetrasiklin } & $3,7 \mathrm{~mm}$ & \\
& $3,4 \mathrm{~mm}$ & $3,7 \mathrm{~mm}$ \\
\hline
\end{tabular}


Uji daya hambat ekstrak etil asetat daun binahong (Anredera coliforlia (Ten.) Steenis) terhadap pertumbuhan bakteri Staphylococcus aureus dan Escherichia coli.

Tabel 4. Hasil pengukuran daya hambat $(\mathrm{mm})$ larutan kontrol positif $(+)$ terhadap Escherichia coli.

\begin{tabular}{ccc}
\hline \multicolumn{3}{c}{ Bakteri uji Escherichia coli } \\
\hline $\begin{array}{c}\text { Larutan kontrol positif } \\
(+)\end{array}$ & $\begin{array}{c}\text { Hasil pengukuran zona hambat } \\
\text { (vertikal, horizontal dan miring) }\end{array}$ & $\begin{array}{c}\text { Rata-rata diameter zona } \\
\text { hambat }(\mathbf{m m})\end{array}$ \\
\hline \multirow{2}{*}{ Tetrasiklin } & $4,2 \mathrm{~mm}$ & \\
& $3,8 \mathrm{~mm}$ & $4,0 \mathrm{~mm}$ \\
& $4,1 \mathrm{~mm}$ & \\
\hline
\end{tabular}

\section{PEMBAHASAN}

Antimikroba adalah bahan yang dapat membunuh atau menghambat pertumbuhan mikroorganisme lainnya. Antimikroba yang berasal dari alam telah banyak digunakan dalam pengobatan.

Binahong (Anredera coliforlia (Ten.) Steenis) adalah salah satu jenis tanaman liar yang dapat diolah secara tradisional dan digunakan untuk pengobatan beberapa jenis penyakit infeksi. Khasiat tanaman ini sebagai antibakteri sangatlah penting. Hal ini disebabkan karena sifatnya yang relatif aman dan tidak menimbulkan resistensi serta tidak menimbulkan bahaya bagi lingkungan sekitar dibandingkan dengan obat-obatan modern.

Ekstraksi merupakan proses penarikan komponen aktif menggunakan pelarut tertentu. Komponen aktif yang diambil adalah senyawa aktif dalam daun binahong (Anredera ciliforlia (Ten.) Steenis). Metode ekstraksi yang digunakan dalam penelitian ini adalah maserasi. Maserasi adalah metode perendaman, dilakukan dengan cara merendam serbuk sampel dalam pelarut. Pemilihan metode maserasi dikarnakan senyawa polifenol rentan terhadap panas sehingga tidak bagus menggunakan metode soxhlet. Penggunaan ekstraksi dengan metode soxhlet dapat merusak senyawa polifenol dalam binahong.

Proses ekstraksi dilakukan dengan menggunakan pelarut etil asetat,karena pelarut etil asetat merupakan pelarut semi polar dan dapat melarutkan senyawa semi polar pada dinding sel seperti aglikon flavonoid (harbone, 1987). Etil asetat juga adalah pelarut polar menengah yang volatil, tidak beracun dan tidak higroskopis. Etil asetat dapat menyaring senyawa-senyawa yang dapat memberikan aktivitas antibakteri diantaranya flavonoid polihidroksi dan fenol yang lain.

$$
\text { Maserasi daun binahong }
$$

dilakukan selama $1 \times 24$ jam dan 
Uji daya hambat ekstrak etil asetat daun binahong (Anredera coliforlia (Ten.) Steenis) terhadap pertumbuhan bakteri Staphylococcus aureus dan Escherichia coli.

diulang 2 kali dengan pengadukan. Pengadukan ini bertujuan untuk mempercepat kontak antara sampel dengan pelarut. Larutan kemudian disaring dengan menggunakan kain saring. Filtrat hasil penyaringan kemudian dipekatkan dengan menggunakan kipas angin. Tujuan pemekatkan ekstrak yaitu untuk memisahkan antara pelarut dengan senyawa aktif dalam daun binahong.

Metode uji daya hambat yang digunakan pada penelitian ini adalah difusi. Metode difusi atau metode difusi agar (Kirby-Bauer Method) adalah metode yang paling sering digunakan. Hal ini dimungkinkan karena dengan metode ini lebih dapat menghemat waktu dan media.

Penelitian ini dilakukan dengan terlebih dahulu menyiapkan alat dan bahan yang digunaka, kemudian dicuci bersih dan dibungkus dengan menggunakan kertas lalu disterilkan di dalam oven dengan suhu $170^{\circ} \mathrm{C}$ selama 1 jam.

Ditimbang Nutrien Agar (NA) sebanyak 2,3 gram lalu dimasukkan kedalam labu erlenmeyer dan ditambah aquadest $100 \mathrm{ml}$ (disuspensikan hinggan menjadi bening). Diangkat, kemudian ditutup dengan kapas, dibiarkan hingga dingin lalu dituang kedalam 2 cawan petri yg telah disediakan masing-masing sebanyak $10 \mathrm{ml}$. Dicampur $10 \mathrm{ml}$ medium agar dengan $0,2 \mathrm{ml}$ suspensi bakteri uji lalu dituangkan kedalam cawan petri yang telah diisi nutrient agar sebelumya (dihomogenkan dan dibiarkan memadat). Sambil menunggu Nutrient Agar (NA) yang berisi bakteri Escherichia coli dan Staphylococcus aureus memadat, dibuat larutan kontrol dan konsentrasi ekstrak daun binahong yang akan diuji daya hambatnya terhadap bakteri tersebut. Untuk larutan kontrol, ditimbang tetrasiklin sebanyak $1 \mathrm{gram}$ lalu dimasukkan kedalam labu erlenmeyer dan ditambahkan dengan aquadest sebanyak $100 \mathrm{ml}$ (dihomogenkan) ditutup dengan aluminium foil. Sedangkan untuk konsentrasi ekstrak daun binahong, di ukur $5 \mathrm{ml}, 10 \mathrm{ml}, 15 \mathrm{ml}$ dan $20 \mathrm{ml}$ kemudian masing-masing dimasukkan kedalam 4 labu erlenmeyer yang telah disediakan lalu ditambahkan $100 \mathrm{ml}$ aquadest (dihomogenkan) ditutup dengan aluminium foil.

Setelah medium agar yang berisis bakteri pada masing-masing cawan petri memadat, diambil kertas cakram yang telah disterilkan lalu direndam pada masing-masing kontrol dan konsentrasi ekstrak daun binahong yang telah dibuat \pm 2 menit 
Uji daya hambat ekstrak etil asetat daun binahong (Anredera coliforlia (Ten.) Steenis) terhadap pertumbuhan bakteri Staphylococcus aureus dan Escherichia coli.

dengan menggunakan pinset lalu dimasukkan kedalam medium agar tersebut (proses ini dilakukan secara aseptik). Setelah selesai cawan petri yang berisi bakteri, kontrol dan konsentrasi ekstrak daun binahong tersebut dibungkus dengan kertas lalu diinkubasi dengan suhu $37^{\circ} \mathrm{C}$ selama 1x24 jam. Kemudian dilakukan pengukuran zona hambat menggunakan jangka sorong. Pengukuran dilakukan dengan melihat zona hambat yg terbentuk lalu menempatkan jangka sorong tersebut secara verikal, horizontal dan miring (dicatat hasil pengukurannya). Setelah diukur panjang zona hambat secara vertikal, horizontal dan miring, hasil pengukuran tersebut ditambah dan dibagi tiga. Hasil dari perhitungan tersebut adalah rata-rata diamter zona hambat $(\mathrm{mm})$ yang terbentuk.

Berdasarkan hasil penelitian yang dilakukan menunjukkan bahwa daya hambat ekstrak etil asetat daun binahong lebih tinggi terhadap bakteri Escherichia coli (gram negatif) dibanding dengan Staphylococcus aureus (gram positif), hal ini ditunjukkan oleh nilai diameter zona hambat terhadap bakteri Escherichia coli lebih besar dari Staphylococcus aureus. Dari hasil percobaan uji daya hambat ekstrak etil asetat daun binahong terhadap pertumbuhan bakteri Escherichia coli dan Staphylococcus aureus pada konsentras $5 \%$ tidak terlihat zona hambat tapi pada konsentrasi $10 \%$, $15 \%$ dan $20 \%$ terlihat zona hambat. Hal ini dapat dikatakan bahwa ekstrak etil asetat daun binahong berpengaruh/berpotensi dapat menghambat pertumbuhan bakteri Staphylococcus aureus dan Escherichia coli, serta berdasarkan diameter zona hambat yang ditimbulkan oleh setiap konsentrasi ekstrak tersebut dapat disimpulkan bahwa semakin tinggi konsentrasi dari suatu sampel maka semakin tinggi pula diameter zona hambat yang ditimbulkannya.

\section{KESIMPULAN}

Dari hasil penelitian yang
dilakukan maka dapat ditarik
kesimpulan bahwa, ekstrak etil asetat daun binahong (Anredera coliforlia (Ten.) Steenis) pada konsentrasi 5\% tidak terlihat zona hambat terhadap bakteri Staphylococcus aureus dan bakteri Escherchia coli sedangkan pada konsentrasi $10 \%, 15 \%$ dan $20 \%$ terlihat zona hambat terhadap kedua bakteri tersebut yaitu $1,7 \mathrm{~mm}, 2,0 \mathrm{~mm}$ dan 2,6 $\mathrm{mm}$ untuk bakteri Staphylococcus aureus dan $1,8 \mathrm{~mm}$, 2,3 $\mathrm{mm}$ dan $2,8 \mathrm{~mm}$ untuk bakteri 
Uji daya hambat ekstrak etil asetat daun binahong (Anredera coliforlia (Ten.) Steenis) terhadap pertumbuhan bakteri Staphylococcus aureus dan Escherichia coli.

Escherichia coli. Hal ini dapat dikatakan bahwa ekstrak etil asetat daun binahong berpengaruh/berpotensi dapat menghambat pertumbuhan bakteri Staphylococcus aureus dan Escherichia coli, serta berdasarkan diameter zona hambat yang ditimbulkan oleh setiap konsentrasi ekstrak tersebut dapat disimpulkan bahwa semakin tinggi konsentrasi dari suatu sampel maka semakin tinggi pula diameter zona hambat yang ditimbulkannya.

\section{DAFTAR PUSTAKA}

Harbone,J.B.,1996. Metode Fitokimia Bandung. Institute Teknologi, Bandung.

Khunafi, M., 2010. Uji Aktivitas Antibakteri Ekstrak Daun Binahong (Anredera coliforlia (Ten.) Steenis) Terhadap Bakteri Staphylococcus aureus dan Pseudomonas aeruginosa. UIN, Malang.

Manoi, F., 2009. Binahong (Anredera coliforlia (Ten) Steenis) Sebagai Obat. Jurnal Warta Penelitian Dan Pengembangan Tanaman Industry 15(1)3.

Murtafiah, A., 2012.Daya Hambat Ekstrak Biji Kopi Robusta (Coffea robusta) Terhadap Staphylococcus mutans. Fakultas Kedokteran Gigi. Jember

Safitri R., et al., 2010. Medium Analisis Mikroorganisme. Trans Info Media, Jakarta.

Setiaji, A., 2009. Uji Aktivitas Antibakteri Ekstrak Petroleum Eter, Etil Asetat Dan Etanol $70 \% \quad$ Rhizome Binahong (Anredera ciliforlia (Tenore) Steenis) Terhadap Staphylococcus aureus ATCC 25923 Dan Escherichia coli ATCC 11229 Serta Skrining Fitokimianya. Skripsi

Susetya, D., 2010. Khasiat Tanaman Binahong. Universitas Indonesia, Jakarta. 